\title{
PENGARUH EFIKASI DIRI DAN KEPUASAN KERJA TERHADAP ORGANIZATIONAL CITIZENSHIP BEHAVIOR (OCB) GURU SMP SWASTA SE KABUPATEN PAMEKASAN MADURA
}

\author{
Hosniyah* $^{*}$
}

Abstract: The objective of this research is to obtain information about the effect of self efficacy and job satisfaction to organizational citizenship behavior (OCB) of private Junior High School teachers at Pamekasan Madura. The research was conducted by using quantitative survey method with path analysis applied in testing hypothesis. The number of 80 teachers as sample was selected by multi stage random sampling. The research conclude; (1). There is direct effect of self efficacy on the OCB. (2). There is direct effect of job satisfaction on the OCB. (3). There is direct effect of self efficacy on the job satisfaction. Therefore, OCB teachers' will be improved by the high quality of self efficacy and job satisfaction.

Keyword: Organizational Citizenship Behavior, Self Efficacy, Job Satisfaction

\section{PENDAHULUAN}

Pendidikan Nasional bertujuan untuk menuntun, membimbing, dan menjadi penunjuk arah bagi peserta didik agar mereka dapat tumbuh dewasa sesuai dengan konsep diri yang sebenarnya, berdaya saing, mampu menghadapi kehidupan masa depan yang penuh dengan tantangan dan perubahan, serta pada gilirannya dapat membangun sebuah peradaban bangsa yang bermartabat. (UU Sisdiknas No. 20 Tahun 2004,).

Kabupaten Pamekasan dengan lembaga pendidikan terlengkap dan tertua di Madura (PAUD, TK, SD, SMP, SMA dan PTS/PTN) berusaha mewujudkan amanah UU Sisdiknas No 20 Tahun 2003 dengan mencanangkan diri sebagai Kota Pendidikan. Usaha yang dilakukan adalah membenahi infrastruktur pendidikan, membesarkan alokasi dana pendidikan, dan memotivasi siswa untuk terus maju dan bersaing di tingkat regional, nasional, maupun internasional.

Dalam konteks mewujudkan cita-cita ideal pendidikan, maka peran paling sentral sebenarnya terletak pada Guru, karena dialah yang paling banyak berinteraksi dan mempengaruhi cara berfikir, bersikap, dan berprilaku siswa, serta berperan penting dalam menggerakkan organisasi sekolah. Tanpa guru, semua fungsi dan peran organisasi sekolah dan siswa tidak akan berjalan dengan maksimal.

Dan kontribusi guru dalam mewujudkan tujuan sekolah ditentukan oleh banyak faktor, diantaranya adalah seberapa besar kecendrungan/kesadaran guru untuk menunjukkan prilaku extra perannya, atau dikenal dengan istilah organizational citizenship behavior (OCB).

Perilaku ekstra peran/organizational citizenship behavior (OCB) sangatlah penting, karena akan meningkatkan kinerja guru dalam mengabdikan dirinya untuk kesuksesan pendidikan. Dengan OCB, guru tidak lagi terikat hanya pada tugas formilnya semata, namun rentang kepeduliannya meliputi tugas-tugas ekstra yang menjangkau masalah tugas-tugas kelembagaan lainnya. Dalam melaksanakan tugas, guru tidak lagi berpikir keuntungan dan reward, namun ia mempunyai keterpanggilan untuk secara total mengabdikan dirinya bagi dunia pendidikan. 
Dan dalam konteks tersebut, perilaku ekstra peran/organizational citizenship behavior (OCB) kurang dimiliki oleh para guru di kabupaten Pamekasan. Sehingga menghambat implementasi dan cita-cita Pamekasan sebagai Kota Pendidikan. http://www.pamekasan.info/kinerja-guru-dikeluhkan.html (diakses 24 januari 2013).

\section{Effikasi Diri}

Menurut Robbins (2013: 249), "self-efficacy (also known as social cognitif theory or social learning theory) refers to an individual's belief that he or she capable of performing a task". Effikasi diri (yang juga dikenal sebagai teori cognitif sosial/teori pebelajaran sosial) merujuk pada keyakinan individual bahwa dirinya mampu mengerjakan suatu tugas.

James L Gibson, et.al. (2012: 113), menyatakan bahwa, "self-efficacy is a belief that we can perform adequately in a particular situation". Artinya effikasi diri adalah keyakinan bahwa kita mempunyai kecakapan yang cukup dalam situasi tertentu.

Bandura (2009: menjelaskan bahwa: "Efficacy beliefs affect self-motivation and action through their impact on goals and aspiration. It is partly on the basis of efficacy beliefs that people choose what goals challenges to undertake, how much effort to invest in the endeavor, and how long to persevere in the past of difficulties". Disini ditegaskan bahwa kepercayaan terhadap kemampuaan diri akan berpengaruh terhadap motivasi diri dan upaya pencapaian tujuan serta aspirasi. Hal ini merupakan bagian yang didasarkan pada keyakinan seseorang terhadap keberhasilannya dalam menyelesaikan tugas secara bertanggung jawab, seberapa besar upaya yang dilakukan, dan berapa lama bertahan dalam kesulitan yang dihadapi.

Dengan demikian, maka effikasi diri merupakan keyakinan yang tertanam dalam diri seseorang berkaitan dengan kemampuannya dalam menyelesaikan tugas, atau pun menghadapi situasi tertentu. Besaran effikasi diri yang dimiliki oleh seorang individu akan sangat menentukan terhadap tingkat keberhasilan yang akan dicapainya.

Menurut Colquitt (2013:167), "self-efficacy, defined as the belief that a person has the capabilities needed to behaviors required for task success". Colquitt memaknai effikasi diri sebagai sebuah keyakinan bahwa seseorang memiliki kemampuan yang dibutuhkan dalam melakukan sebuah pekerjaan dengan berhasil.

Kinicki dan Fugate (2012: 125) menyatakan, "self-efficacy is a person's belief about his or her chances of successfully accomplishing a specific task". Effikasi diri adalah keyakinan seseorang terhadap peluang dirinya untuk berhasil dalam menyelesaikan suatu tugas tertentu. Berikut adalah mekanisme terbentuknya effikasi diri yang selanjutnya mengantarkan individu pada kesuksesan atau kegagalan. Mekanisme tersebut secara ringkas dapat dilihat pada gambar berikut:

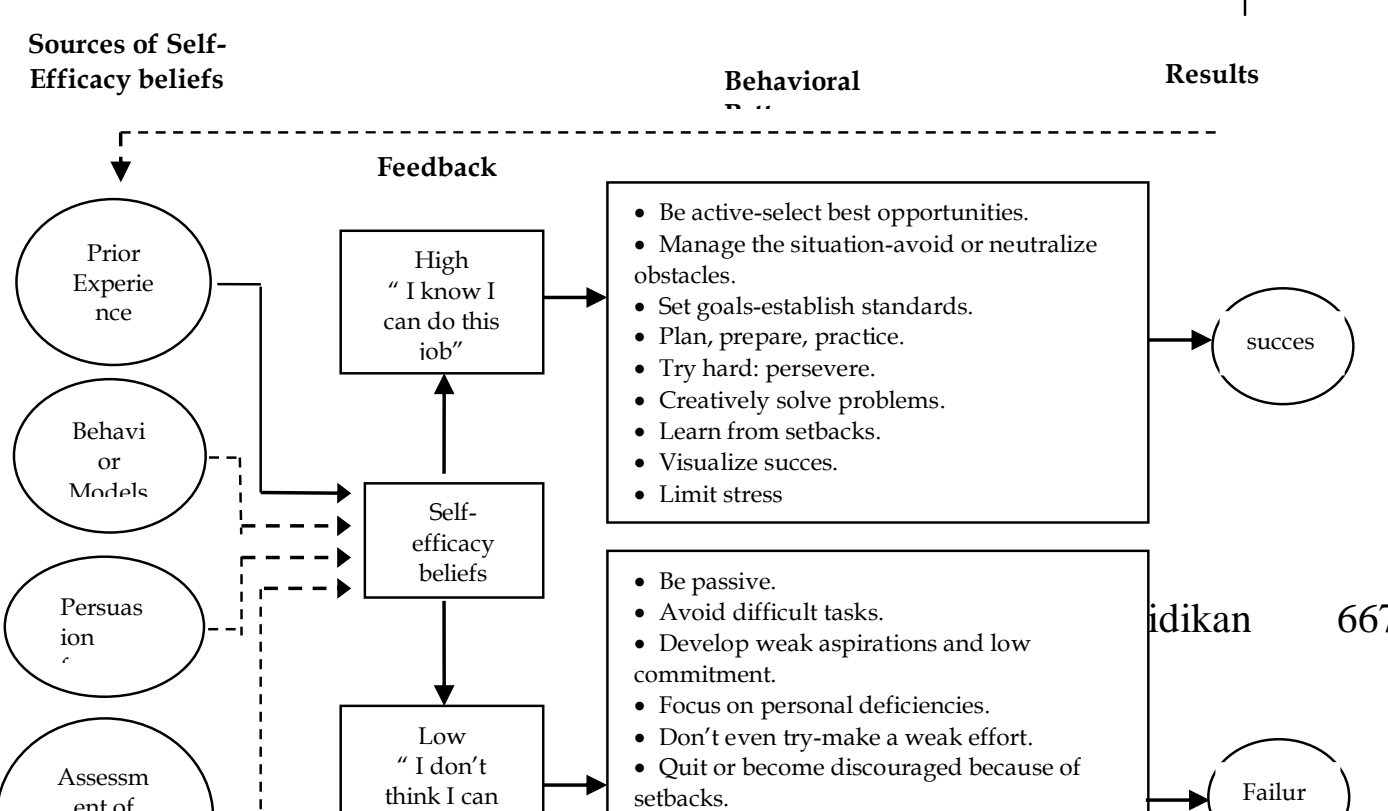




\section{Gambar 1. mekanisme effikasi diri}

Greenberg dan Baron (2003:88) menegaskan, "self-efficacy -the belief in one's own capacity to execute courses of action required to reach specific levels of performance", yang bisa dimaknai bahwa self-efficacy merupakan keyakinan terhadap kapasitas diri dalam mengeksekusi beberapa tindakan khusus yang diperlukan untuk mencapai tingkat kinerja yang diinginkan. Yang menurut Greenberg dan Baron memiliki 3 dimensi, yaitu: a. Besarnya (magnitude), merujuk pada tingkat kesulitan tugas yang diyakini dapat ditangani oleh individu. Contohnya; A yakin bisa menyelesaikan dengan benar dan tepat waktu 8 soal dari 10 soal yang diberikan, dan B merasa yakin bisa mengerjakan 7 soal dari 10 soal, maka A memiliki tingkat effikasi diri yang lebih tinggi dibanding B.

b. Kekuatan (strength), yaitu seberapa kuat keyakinan individu menyelesikan sebuah pekerjaan pada level tertentu. Pada contoh point a, effikasi diri A kuat, dan effikasi diri B lemah.

c. Generalitas (generality), menunjukkan seberapa luas situasi dimana keyakinan terhadap kemampuan tersebut berlaku. Jika B berfikir bisa menyelesaikan soal yang berbeda dengan kualitas jawaban yang sama dengan soal sebelumnya, sementara A tidak berfikir demikian, maka generalitas B lebih baik dibandingkan A.

Secara ringkas, Fred Luthans (2011:203) menyatakan, "Self-efficacy refers to an individual's convection (or confidence) about his or her abilities to mobilize the motivation, cognitif resources, and courses of action needed to successfully execute a specific task within a given context. Effikasi diri mengacu pada keyakinan individual tentang kemampuan dirinya untuk memobilisasi motivasi diri, sumber daya kognitif, dan tindakan tertentu yang diperlukan agar berhasil melaksanakan tugas-tugas dalam konteks yang spesifik.

Dari beberapa konsep tentang effikasi diri sebagaimana diuraikan di atas, maka dapat disintesiskan bahwa effikasi diri merupakan keyakinan seseorang untuk memotivasi diri, memberdayakan sumberdaya cognitif, dan melakukan tindakan tertentu agar berhasil menyelesikan tugas secara spesifik dengan indikator: generalitas (generality), kekuatan (strength), dan besaran (magnitude).

\section{Kepuasan Kerja}

Colquitt, Lepine dan Wesson (2013:96) menyatakan: "job satisfaction is a pleasurable emotional state resulting from the appraisal of one's job or job experiences. It represents how you feel about your job and what you think about your job". Kepuasan kerja adalah sebuah ungkapan emosional yang menyenangkan.

Menurut Lockce (2011:141), "job satisfaction as a pleasurable or positive emotional state resulting from the appraisal of one's job or job experience". Kepuasan kerja diartikan sebagai suatu kondisi emosional yang menyenangkan sebagai hasil penilaian dari pekerjaan atau pengalaman kerja. 
Hal senada diungkapkan oleh Luthans (2011:141), "job satisfaction is a result of employees' perception of how well their job provides those thing that a viewed as important". Kepuasan kerja merupakan hasil dari persepsi pegawai tentang seberapa bagus pekerjaan mereka dalam memberikan segala sesuatu yang dianggap perlu.

Kinicki dan Fugate (2012:161), menyatakan, "job satisfaction is an affective or emotional response toward various facets of one's job". Kepuasan kerja merupakan reaksi afektif atau emosional terhadap berbagai aspek yang dimiliki oleh suatu pekerjaan.

Dalam pengertian ini, kepuasan kerja tidak bisa dipahami dalam satu konsep, sebab ia mengandung kompleksitas, contohnya ada pekerja yang senang dengan suatu aspek dalam pekerjaannya, namun merasa tidak suka dengan aspek lainnya. Selain itu, sesuatu yang dianggap memuaskan bagi seorang pegawai belum tentu memuaskan bagi pegawai lainnya.

Oleh sebab itu, Colquitt (2013:98-100) merangkumnya dalam 5 dimensi utama, yaitu:

a. Kepuasan bayaran (pay satisfaction), yaitu perasaan pegawai terhadap gaji yang diterima (kepantasan, terjamin, dan memadai).

b. Kepuasan promosi (promotion satisfaction), yaitu perasaan pegawai terhadap aturan dan pelaksanaan promosi yang dilakukan (adil, berkala, dan berdasarkan kapasitas).

c. Kepuasan supervisi (supervision satisfaction), yaitu persepsi pegawai tentang atasannya (kompeten, ramah, komunikatif, atau sebaliknya, malas, menggganggu, bersikap dingin).

d. Kepuasan dengan rekan kerja (co-worker satisfaction), penilaian pegawai terhadap rekan kerja lainnya (pintar, membantu, menarik, atau sebaliknya, malas, penggosip dan membosankan).

e. Kepuasan dengan pekerjaan itu sendiri (satisfaction with work itself), perasaan pegawai terhadap pekerjaan itu sendiri (menantang, menyenangkan, prestisius, membutuhkan suatu keahlian tertentu, atau memasung kreatifitas, terjebak pada rutinitas).

Dari beberapa dimensi di atas dapat disimpulkan bahwa seorang pekerja akan merasa puas apabila nilai-nilai yang diinginkannya tersedia dalam organisasi tempatnya bekerja, demikian juga sebaliknya.

Selain itu Greenberg dan Baron (2003:148) mengatakan, "job satisfaction as individuals' positive or negatif attitudes toward their jobs". Kepuasan kerja merupakan sikap positif atau negatif seseorang berkaitan dengan pekerjaannya.

Sehingga McShane (2010:108) mengatakan, "job satisfaction a person's evaluation of his or her job and work context, is probably the most studied attitude in organizational behavior". Kepuasan kerja adalah evaluasi seseorang dari pekerjaannya dan konteks kerja, mungkin sikap yang paling banyak dipelajari dalam perilaku organisasi.

Spector (1997:2) juga menyatakan, "Job satisfaction is simply how people feel about their jobs and different aspect of their jobs. It is the extent to which people like (satisfaction) or dislike (dissatisfaction) their jobs". Kepuasan kerja dapat disimpulkan sebagai bagaimana cara seseorang merasakan pekerjaan dan berbagai aspek pekerjaannya. Itu juga berarti sampai sejauh mana seseorang menyukai/tidak menyukai pekerjaannya.

Dari berbagai pandangan tentang kepuasan kerja di atas maka dapat disintesiskan bahwa kepuasan kerja adalah perasaan menyenangkan yang dirasakan individu yang didasarkan atas penilaian dan pengalaman kerja dengan indikator: kepuasan terhadap pekerjaan itu sendiri, kepuasan promosi, kepuasan supervisi, kepuasan terhadap rekan kerja, kepuasan komunikasi, kepuasan penghargaan. 


\section{Organizational Citizenship Behavior}

Menurut Kinicki dan Fugate (2012:163), "organizational citizenship behavior (OCBs) consist of employee behaviors that are beyond the call of duty", dalam pandangan ini OCB merupakan perilaku pegawai yang berada di luar panggilan tugas.

Atau, dalam pandangan Schnake (1997:57), "OCB is behavior that goes beyond the formal requirement of $a$ job", yang bermakna bahwa OCB adalah perilaku yang melampaui persyaratan formal pekerjaan. Dengan demikian, maka OCB merepresentasikan karakter pegawai yang bersedia untuk bekerja melampaui tugas dan pekerjaan pokoknya.

Robbins (2013: 61) menyatakan, "citizenship behavior the discretionary behavior that is not part of an employee's formal job requirements, and that contributes to the psychological and social environment of the work place". Perilaku citizen merupakan perilaku pilihan yang tidak menjadi bagian dari kewajiban kerja formal seorang pegawai, dan secara psikologis maupun sosial berkontribusi terhadap lingkungan organisasi. Kontribusi psikologis dan sosial ini pada gilirannya akan meningkatkan efektifitas organisasi.

Lebih lanjut, McShane dan Glinow (2010: 17) menyatakan, “organizational citizenship behaviors (OCBs)-various forms of cooperation and helpfulness to others that support the organization's social and psychological context". Yakni, OCB merupakan beragam bentuk kerjasama dan pertolongan terhadap orang lain yang mendukung terhadap situasi sosial dan psikologis organisasi.

Oleh sebab itu, Newstrom (2011: 232) menegaskan bahwa: Organizational citizenship (also called prosocial behavior) is often marked by its spontaneity, its voluntary nature, its constructive impact on results, and its unexpected helpfulness or cooperativeness to others. OCB sering disebut sebagai perilaku pro sosial yang ditandai oleh; sportifitas, sifat sukarela, selalu mendatangkan dampak positif, suka menolong secara tidak terduga, dan sangat kooperatif pada orang lain.

Beberapa konsep di atas selaras dengan apa yang dikemukakan Organ (2013: 3), bahwa: Organizational citizenship behavior (OCB) represents individual behavior that is discretionary, not directly or explicitly recognized by the formal reward system, and that in the aggregate promotes the effective functioning of the organization.

Pendapat ini merepresentasikan bahwa, organizational citizenship behavior (OCB) merupakan perilaku individu yang mencerminkan sifat bebas (discretionary), yang tidak berhubungan langsung secara eksplisit dengan sistem penghargaan formal, namun secara keseluruhan dapat mendorong fungsi efektif dari organisasi, sekaligus bersifat sukarela karena perilaku tersebut bukan merupakan persyaratan yang harus dilaksanakan dalam peran tertentu atau deskripsi jabatan, yang secara jelas dituntut berdasarkan kontrak dengan organisasi, melainkan sebagai sebuah pilihan pribadi.

Colquitt (2013: 38), menyatakan: "Citizenship behavior, which is defined as voluntary employee activities that may or may not be rewarded but that contribute to the organization by the improving overall quality in the setting in which work takes place. Perilaku citizen yang sering diartikan sebagai kerelaan pegawai dalam melakukan berbagai pekerjaan dengan atau tanpa dibayar namun berkontribusi terhadap peningkatan kualitas organisasi secara keseluruhan.

Dalam pandangan ini, Colquitt memungkinkan adanya sistem reward dalam perilaku OCB. Hal ini berbeda dengan pendapat Organ yang menyatakan bahwa OCB sama sekali tidak berhubungan dengan sistem reward. Dengan demikian, Organ menekankan bahwa OCB benar-benar merupakan sebuah perilaku sukarela yang terpisah dari sistem reward. Namun demikian, keduanya sepakat bahwa OCB merupakan perilaku sukarela yang dilakukan untuk kemajuan organisasi. 
Lebih lanjut Greenberg \& Baron (2003: 408) menyatakan; Organizational citizenship behavior $(O C B)$ an informal form of behavior in which people go beyond what is formally expected of them to contribute to the well-being of their organizational and those in it. Di sini, OCB merupakan bentuk informal perilaku seseorang yang bisa melampaui apa yang secara resmi diharapkan dapat memberikan kontribusi terhadap kesejahteraan organisasi dan orang-orang di dalamnya. OCB mengacu pada perilaku ekstra yang melebihi persyaratan minimum dari sebuah pekerjaan.

Dan dalam implementasinya Organ, Greenberg \& Baron ( 2003: 409) menjelaskan 5 dimensi perilaku dalam OCB, yaitu:

a. Altruisme (altruism), yaitu mengutamakan kepentingan orang lain, seperti membantu teman sekerja dalam menyelesaikan pekerjaaannya.

b. Kesadaran dan ketelitian (conscientiousness), seperti efisien dalam menggunakan waktu, tingkat kehadiran tinggi, dan datang lebih awal.

c. Kebajikan diri (civic virtue), keterlibatan diri secara politis namun bertanggung jawab dalam mengambil kebijakan organisasi.

d. Kejujuran (sportsmanship), mengabaikan serta tidak mengeluh terhadap tekanan dan gangguan kecil yang timbul di tempat kerja.

e. Kesopanan/keteladanan (courtesy), menghindari perilaku yang bisa menimbulkan masalah bagi rekan sekerja lainnya.

Sementara Podsakoff et.al, (2000: 516) merangkum perilaku OCB dalam 7 dimensi, yaitu: (1) Perilaku membantu (helping behavior), (2) kejujuran (sportsmanship), (3) loyalitas organisasi (organizational loyalty), (4) berperilaku sesuai dengan aturan organisasi (organizational compliance), (5) inisiatif diri (individual initiative), (6) kebajikan diri (civic virtue), dan (7) pengembangan diri (self development).

Dari beberapa pendapat tentang organizational citizenship behavior (OCB) dapat disintesiskan bahwa OCB adalah tindakan seseorang secara sukarela di luar peran utamanya sebagai pegawai yang dapat berkontribusi positif terhadap perkembangan organisasi dengan indikator: altruism, kesadaran, kejujuran, kesopanan, dan kebajikan.

\section{METODE}

Penelitian ini dilakukan di Sekolah Menengah Pertama Swasta se Kabupaten Pamekasan. Dengan populasi seluruh guru yang mengajar di SMP Swasta sePamekasan, dan karena sangat luasnya wilayah populasi, maka peneliti menggunakan teknik probability sampling dengan memberi peluang yang sama bagi setiap unsur (anggota) populasi untuk dipilih menjadi anggota sampel. Teknik ini meliputi simple random sampling, proportionate stratified random sampling, disproportionate stratified random sampling, dan cluster sampling. Dari beberapa teknik tersebut, maka penarikan sampel dalam penelitian ini ditetapkan melalui beberapa tahapan secara acak (multi stage random sampling).

Data penelitian dikumpulkan melalui penyebaran kuesioner yang didesain dalam bentuk skala Likert. Dengan menggunakan metode survey kausal dengan teknik analisis jalur (Path Analysis). Pendekatan ini dipilih untuk menganalisis pola hubungan antar variabel dengan tujuan untuk mengetahui pengaruh langsung maupun tidak langsung seperangkat variabel bebas (eksogen) terhadap variabel terikat (endogen).

Sebelum kuesioner digunakan dalam penelitian ini, maka terlebih dahulu dilakukan uji coba untuk menentukan validitas dan dan reabilitas intrumen. Hasil tersebut digunakan sebagai instrument untuk mengambil data penelitian di lapangan. Analisis data meliputi; 1 . deskripsi data, 2. uji persyaratan normalitas, uji regresi dan uji korelasi, 3. Analisis jalur yang meliputi analisis model, pengujian hipotesis dan 
penentuan tingkat pengaruh. Sedangkan waktu penelitian kurang lebih dilakukan selama 4 bulan.

\section{HASIL DAN PEMBAHASAN}

Hipotesis pertama: (1). Terdapat pengaruh langsung positif effikasi diri (X1) terhadap Organizational Citizenship Behavior (OCB) (X3).

Korelasi antara effikasi diri dengan Organizational Citizenship Behavior (OCB) sebesar 0,557. Dengan nilai koefisien $t_{\text {hitung }}$ sebesar $5,92>t_{\text {tabel }}$ sebesar 2,38 pada $\alpha=0,01$ sehingga dengan demikian dapat dinyatakan bahwa korelasi antara $X_{1}$ dan $X_{3}$ sangat signifikan.

Dan dari hasil perhitungan analisis jalur, pengaruh langsung effikasi diri terhadap organizational citizenship behavior (OCB), nilai koefisien jalur sebesar 0,315 dimana nilai koefisien $t_{\text {hitung }}$ sebesar 2,622. Nilai Koefisien $t_{\text {tabel }}$ untuk $a=0,05$ sebesar 1,99. Oleh karena nilai koefisien $t_{\text {hitung }}$ lebih besar dari pada nilai $t_{\text {tabel }}$ maka dengan demikian Ho ditolak dan Hi diterima yaitu bahwa effikasi diri berpengaruh secara langsung terhadap organizational citizenship behavior (OCB) dapat diterima.

Hasil analisis hipotesis pertama memberikan temuan bahwa effikasi diri berpengaruh secara langsung positif terhadap organizational citizenship behavior (OCB). Dengan demikian dapat disimpulkan bahwa organizational citizenship behavior (OCB) dipengaruhi secara langsung positif oleh effikasi diri. Meningkatnya effikasi diri akan mengakibatkan peningkatan organizational citizenship behavior (OCB) sebesar 31,5\%.

Hal ini selaras dengan pendapat Quick dan Nelson (2009: 89) yang mengatakan: "Individuals with positif affect are more satisfied with their jobs. In addition, those with positif affect are more likely to help others at work and also engage in more organizational citizenship behaviors (OCBs)".

Individu yang memiliki sikap positif akan lebih puas dengan pekerjaan mereka. Dan sebagai tambahan, mereka yang memiliki sikap positif akan lebih suka untuk membantu rekan sekerja dalam pekerjaannya dan kerap kali meningkatkan perilaku OCB.

Quick dan Nelson (2009: 89) memaknai effikasi diri sebagai sikap positif, sebagaimana disampaikan, "individual who focus on the positif aspect of themselves, other people, and the work in general are said to have positif affect. Seseorang yang fokus pada aspek positif tentang dirinya, orang lain, dan pekerjaan secara umum dikatakan memiliki sikap positif.

Pendapat di atas senada dengan pernyataan Ainimazita Mansour, Amer Darus, dan Mohd Hasan Dali (2013: 3), "self-efficacy has a direct, positive effect on OCBO". Effikasi diri memiliki pengaruh langsung positif pada OCBO.

Berdasarkan uraian di atas sangat jelas bahwa effikasi diri akan berpengaruh terhadap organizational citizenship behavior (OCB). Effikasi diri yang tinggi merupakan modal luar biasa bagi seorang guru dalam mendedikasikan dirinya melebihi tuntutan pekerjaannya (berprilaku OCB).

\section{Hipotesis kedua: (2). Terdapat pengaruh langsung positif kepuasan kerja (X2) terhadap Organizational Citizenship Behavior (OCB) (X3).}

Korelasi antara kepuasan kerja dengan Organizational Citizenship Behavior (OCB) sebesar 0,573. Dengan nilai koefisien $t_{\text {hitung }}$ sebesar $6,17>t_{\text {tabel }}$ sebesar 2,38 pada $\alpha=0,01$ sehingga dengan demikian dapat dinyatakan bahwa korelasi antara $X_{2}$ dan $X_{3}$ sangat signifikan. 
Dari hasil perhitungan analisis jalur, pengaruh langsung kepuasan kerja terhadap Organizational citizenship behavior (OCB), nilai koefisien jalur sebesar 0,363 dan nilai koefisien $t_{\text {hitung }}$ sebesar 3,022 sedangkan nilai koefisien $t_{\text {tabel }}$ untuk $\alpha=0,05$ sebesar 1,99. Oleh karena nilai koefisien $t_{\text {hitung }}$ lebih besar dari pada nilai koefisien $t_{\text {tabel }}$ maka Ho ditolak dan Hi diterima, dengan demikian kepuasan kerja berpengaruh secara langsung terhadap Organizational citizenship behavior (OCB) dapat diterima.

Hasil analisis hipotesis kedua menghasilkan temuan bahwa kepuasan kerja berpengaruh secara langsung positif terhadap organizational citizenship behavior (OCB). Berdasarkan hasil temuan tersebut dapat disimpulkan bahwa organizational citizenship behavior (OCB) dipengaruhi secara langsung positif oleh kepuasan kerja. Meningkatnya kepuasan kerja akan mengakibatkan peningkatan organizational citizenship behavior (OCB) sebesar 36,3\%.

Hal ini selaras dengan pendapat Snake (1997: 57) yang menyatakan, “. . OCB is caused by good treatment from the supervisor and by job satisfaction". OCB disebabkan oleh mekanisme supervisi yang baik dan kepuasan kerja. Hal ini sangat wajar terjadi, karena individu yang merasa nyaman dengan cara kerja atasan dan menyukai pekerjaannya cenderung berkinerja melebihi keharusan.

Berkaitan dengan sikap ini Colquitt (2013: 114) menjelaskan; "Satisfied employees engage in more frequent "extra mile" behaviors to help their coworkers and their organization. Positive feelings incrreas their desire to interact with others and often result in spontaneous acts of helping and other instances of good citizen".

Pegawai yang puas cenderung semakin meningkatkan frekuensi perilaku "extra mile" untuk membantu rekan kerja dan organisasi mereka. Perasaan positif meningkatkan kecenderungan mereka dalam berinteraksi secara sportif untuk membantu sesama pekerja maupun contoh-contoh perilaku citizen lainnya.

Pendapat senada disampaikan oleh Robbins (2013: 118)," job satisfaction shoud be a major determinant of an employee's organizational citizenship behavior. Satisfied employees would seem more likely to talk positively about the organization, help others, and go beyond the normal expectations in their job, perhaps because they want to reciprocate their positive experiences".

Robbins memandang kepuasan kerja sebagai faktor utama dari perilaku OCB pegawai. Pegawai yang puas memiliki argumentasi positif tentang organisasi, membantu rekan sekerja, melampaui perilaku yang diharapkan, yang mungkin sebagai balasan terbaik atas pengalaman positif yang dirasakan.

Berdasarkan uraian di atas dapat dijelaskan bahwa guru yang memiliki kepuasan kerja tinggi akan berpengaruh terhadap lahirnya prilaku organizational citizenship behavior (OCB). Kepuasan yang mereka dapatkan di tempat kerja membuat mereka lebih mencintai pekerjaan dan organisasi tempat mereka bekerja. Sebagai konsekwensinya mereka melakukan performa terbaik dalam pekerjaan dan mendedikasikan yang terbaik untuk organisasi.

\section{Hipotesis ketiga: (3). Terdapat pengaruh langsung positif effikasi diri (X1) terhadap kepuasan kerja $(\mathrm{X} 2)$.}

Korelasi antara effikasi diri dengan kepuasan kerja sebesar 0,667. Dengan nilai koefisien $t_{\text {hitung }}$ sebesar 7,91 $>t_{\text {tabel }}$ sebesar 2,38 pada $\alpha=0,01$ sehingga dengan demikian dapat dinyatakan bahwa korelasi antara $X_{1}$ dan $X_{2}$ sangat signifikan.

Dari hasil perhitungan analisis jalur, pengaruh langsung effikasi diri terhadap kepuasan kerja, nilai koefisien jalur sebesar 0,667 dimana nilai koefisien $t_{\text {hitung }}$ sebesar 5,553 . Nilai Koefisien $t_{\text {tabel }}$ untuk $a=0,05$ sebesar 1,99 . Oleh karena nilai koefisien $t_{\text {hitung }}$ 
lebih besar dari pada nilai $t_{\text {tabel }}$ maka dengan demikian Ho ditolak dan Hi diterima yaitu bahwa effikasi diri berpengaruh secara langsung terhadap kepuasan kerja dapat diterima.

Hasil analisis hipotesis pertama memberikan temuan bahwa effikasi diri berpengaruh secara langsung positif terhadap kepuasan kerja. Dengan demikian dapat disimpulkan bahwa kepuasan kerja dipengaruhi secara langsung positif oleh effikasi diri. Meningkatnya effikasi diri akan mengakibatkan peningkatan kepuasan kerja sebesar $66,7 \%$.

Hal ini sesuai dengan pendapat Kristof (1997: 30) yang menyatakan; " the fit between the individual and the job has been showen to be an important influence on employee job satisfaction". Kesesuaian antara individu dengan pekerjaan dipandang memiliki pengaruh penting terhadap kepuasan kerja. Lebih lanjut Quick dan Nelson (2009: 89) mengatakan, "individuals with positive affect are more satisfied with their job". Individu dengan sikap positif akan lebih puas dengan pekerjaan mereka.

Hal ini dikarenakan, mereka yang memiliki penilaian positif senantiasa optimistis dengan kemampuannya dalam meraih kesuksesan. Apabila menghadapi kesulitan atau rintangan dalam pekerjaan, mereka berusaha maksimal dan terus gigih memperjuangkannya. Ini memiliki kesesuaian dengan hasil riset yang disampaikan Robbin dan Judge (2013: 116) berikut; "Research has shown that people who have positive selfevaluations -who belief in their inner worth and basic competence-are more satisfied with their jobs than those with negatif core-self evaluatons. Not only do they see their work as more fulfilling and challenging, they are more likely to gravitate toward challenging jobs in the first place".

Riset telah menunjukkan bahwa seseorang yang memiliki evaluasi diri positif yaitu kepercayaan akan nilai dalam dirinya dan kompetensi dasar- adalah lebih puas dengan pekerjaan mereka dibandingkan dengan mereka yang memiliki evaluasi diri negatif. Mereka tidak hanya melakukan pekerjaan sebagai sesuatu yang sangat menantang dan menarik, akan tetapi mereka senantiasi berotasi dengan tantangan pekerjaan pada lini terdepan.

Pernyataan Robbins tersebut sangat selaras dengan beberapa dimensi sikap dari effikasi diri yang tinggi. Tidak mengherankan jika kemudian Greenberg dan Baron (2003: 89) mengatakan, "not surprisingly, people who are higher in self-efficacy also tend to be happier with their work and with their lives in general". Tidaklah mengagetkan jika seseorang yang memiliki effikasi diri tinggi cenderung lebih meyukai pekerjaan dan kehidupannya secara general.

Dari beberapa uraian di atas dapat disimpulkan bahwa, effikasi diri memiliki pengaruh positif terhadap kepuasan kerja. Semakin tinggi effikasi diri seorang guru, semakin tinggi pula tingkat kepuasannya dalam pekerjaan.

\section{PENUTUP}

Kesimpulan. Berdasarkan analisis terhadap hasil penelitian yang telah dibahas, maka dapat disampaikan beberapa temuan penelitian sebagai berikut:

1. Terdapat pengaruh langsung positif effikasi diri terhadap organizational citizenship behavior (OCB). Artinya meningkatnya effikasi guru akan mempengaruhi meningkatnya perilaku OCB.

2. Terdapat pengaruh langsung positif kepuasan kerja terhadap organizational citizenship behavior (OCB). Artinya bila kepuasan kerja guru meningkat, maka perilaku OCB akan meningkat. 
3. Terdapat pengaruh langsung positif effikasi diri terhadap kepuasan kerja. Artinya bila guru memiliki effikasi diri yang tinggi, maka akan mendorong peningkatan kepuasan kerja.

Saran. Berdasarkan kesimpulan di atas dapat dikemukakan beberapa saran untuk mendorong lahirnya prilaku organizational citizenship behavior (OCB), sebagai berikut:

1. Semua komunitas sekolah harus menyadari bahwa effikasi diri merupakan faktor penting dalam meningkatkan prilaku OCB guru. Untuk itu, perlu dilakukan berbagai upaya seperti; pelatihan yang dapat meningkatkan kecakapan guru, pemberian tugas baru yang menantang, serta menciptakan suasana yang mendukung terhadap tumbuhnya kepercayaan diri pada guru.

2. Para pengambil kebijakan hendaknya memperhatikan masalah kepuasan kerja guru dengan cara menanamkan kecintaan pada pekerjaan, memberi penghargaan terhadap prestasi yang dicapai, memberikan teladan yang baik, mendorong terciptanya suasana kerja yang menyenangkan serta menerapkan mekanisme supervisi dan promosi yang baik.

3. Penelitian ini dapat dimanfaatkan untuk meningkatkan organizational citizenship behavior (OCB) guru SMP Swasta di Kabupaten Pamekasan dengan menumbuhkan kesadaran mereka akan pentingnya faktor effikasi diri dan kepuasan kerja. 


\section{DAFTAR RUJUKAN}

Bandura, A, "Cultivate Self-Efficacy for Personal and Organizational Effectiveness" eds. E A Locke, Handbook of Principles of Organization Behavior. New York: Willey, 2009. http:// www.uky.edu/ (diakses: 10 maret 2013).

Bandura, Albert, "Perceived Self-Efficacy in Cognitive Development and Functioning", Journal Educational Psychologist, Vol. 28 (2), Spring 1993.

Colquit, Jason A., Jeffery A. Lepine, Michael J Wesson, organizational behavior, improving performance and commitment in the workplace. New York: McGraw-Hill, 2013.

Fassina, Neil E, David A Jones, Krista L Uggerslev, “Relationship Clean-Up Time: Using Meta-Analysis to Clarify Relationship Among Job Satisfaction, Perceived Fairness, and Citizenship Behavior" Journal of Management, Vol. 34 (2) Spring 2008.

Gibson, James L, et.al., Organizaton; Behavior, Structure, Process. New York: McGraw-Hill, 2012.

Greenberg, Jerald dan Robert A Baron, Behavior in Organization. New Jersey: Prentice Hall, 2003.

http://www.pamekasan.info/kinerja-guru-dikeluhkan.html (diakses 24 januari 2013).

Ivancevich, John M, Robert Konopaske, Michael T Mattison, Perilaku dan Manajemen Organisasi terjemahan Gina Gania. Jakarta: Erlangga, 2005.

Kinicki, Angelo dan Mel Fugate, Organizational Behavior; Key Concept, Skills, and Best Practices. New York: McGraw-Hill, 2012.

Lai, Ming-Cheng dan Yen-Chun Chen, "Self-Efficacy, Effort, Job performance, Job Satisfaction and Turnover Intention: The Effect of Personal Characteristics on Organization Performance", International Journal of Innovation, Management and Technology, Vol. 3 (4), Spring. 2012. http://aiars.org/ijebm/journal/ (diakses: 03 Pebruari 2013).

Luthans, Fred, organizational behavior . New York: McGraw-Hill,2011.

Mansor, Ainimazita, Amer Darus, Mohd Hasani Dali, "Mediating Effect of Self-Efficacy on Self-Leadership and Teachers' Organizational Citizenship Behavior: A Conceptual Framework", International Journal of Economics Business and Management Studies-IJBMS, Vol.2 (1), Spring 2013.

McShane dan Von Glinow, Organizational Behavior; Emerging Knowledge and Practice for the Real World. Ne York: McGraw-Hill, 2010.

Mulyasana, Dedy, Pendidikan bermutu dan berdaya saing. Bandung: Remaja Rosdakarya, 2011.

Newstom, Jhon W, Organizational Behavior; Human Behavior at Work. New York: McGrawHill, 2011.

Podsakoff, Philip M, Scott B MacKenzie, Julie Beth Paine, Daniel G Bachrach, "Organizational Citizenship Behavior: A Critical Review of The Theoretical and Empirical Literature and Suggestions for Future Research" Journal of Management, Vol. 26 (3), Spring 2000. 
Prihatsanti, Unika dan Kartika Sari Dewi "hubungan antara iklim organisai dan Organizational citizenship behavior (OCB) pada guru SD Negeri di Kecamatan Mojolaban Sukoharjo" Jurnal Psikologi Undip Vol. 7 (1), Spring 2010.

Quick, James Campbell, Debra L Nelson, Principle of Organizational Behavior, Realities and Challenenges. South-Western: Engage in Learning, 2009.

Robbins, Stephen P, Timothy A Judge, Organizational Behavior. Inggris: Pearson Educational Limited, 2013.

Rosa, Valentina dan Guido Alessandri, “Teachers' Efficacy: Promoting Job Commitment and Job Satisfaction", FOCUS, Vol. 5 (3/4), Spring. 2009. http:// preventiontoday.ispesl.it/ (diakses:03 pebruari 2013).

Spector, Paul E, Job Satisfaction; Application, Assessment, Causes and Consequences. California: Sage publications, 1997.

Sugiyono, Statistika untuk Penelitian, Bandung: Alfabeta, 2012.

Zil, Zuhil, "karimatafm.com" http://www.karimatafm.com/news/ (diakses 24 Januari 2013). 